\title{
Retraction Note to: Preference for immediate reinforcement over delayed reinforcement: relation between delay discounting and health behavior
}

\author{
Shane Melanko $\cdot$ Kevin T. Larkin
}

Published online: February 13, 2015

(C) Springer Science+Business Media New York 2015

Retraction Note to: J Behav Med (2013) 36:34-43
DOI 10.1007/s10865-012-9399-z

At the request of Kevin Larkin, this article has been retracted due to research misconduct of Shane Melanko. Mister Melanko was solely responsible for the actions that resulted in the retraction of this article, and Dr. Larkin was unaware of his actions until after the article was published. No other published work was implicated during the investigation of research misconduct, and any data collected by Mr. Melanko for other studies have been discarded and will not be analyzed or published.

The online version of the original article can be found under doi:10.1007/s10865-012-9399-z.

The first retraction note of the article can be found under doi:10.1007/s10865-014-9602-5.

S. Melanko $(\bowtie) \cdot$ K. T. Larkin

Department of Psychology, West Virginia University,

53 Campus Drive, 1212 Life Sciences Building, Morgantown,

WV 26505, USA

e-mail: Shane.melanko@mail.wvu.edu 